\title{
Isolation, Characterization and Identification of Putative Bacterial Endophytes from Some Plants in Hot Springs, South Dakota
}

\author{
Mada Faisal Ashkan ${ }^{1 *}$ and Bruce Bleakley ${ }^{2}$ \\ ${ }^{1}$ Biological Science Department, King Abdulaziz University, Rabigh, Saudi Arabia \\ ${ }^{2}$ Biology and Microbiology Department, South Dakota State University, \\ Brookings, United States \\ *Corresponding author
}

A B S T R A C T

Endophytic bacteria to promote plant growth by facilitating nutrient acquisition through the fixation of nitrogen, solubilizing phosphate, producing siderophores, producing plant growth hormones, or enzyme1- aminocyclopropane-1- carboxylate (ACC) deaminase and

\section{Keywords}

Endophytic bacteria,

Plant growth promotion, Isolation, Characterization, Identification.

Article Info

Accepted:

14 May 2017

Available Online:

10 June 2017 protecting plants from pathogens, via production of antibacterial or antifungal agents, or outcompeting pathogens for nutrients. Isolation and development of new selected plant growth promoting endophytic bacterial strains could be one of the many new approaches that are needed to aid the growth and health of agricultural crops, to eliminate or minimize the harmful effects of inorganic fertilizers, and to conserve organic and inorganic soil nutrients. The aim of this study was to isolate, characterize and identify endophytic bacteria from plants growing along the stream banks in Hot Springs, South Dakota. The bacterial endophytes were isolated, identified and screened in vitrofor morphological features (Gram stain, Gram morphology, and colony morphology). Further, isolates exhibiting difference in morphological features were selected for molecular identification through partial 16S-rRNA gene sequencing. Twenty-five endophytic bacteria strains were isolated from monocotyledons plants, viz. Typha, Bromus tectorum and Festuca and eight strains from a dicotyledonous plant, Nasturtium officinale. All the isolated endophytic bacteria were identified as different bacterial strains belonging to Bacillus thuringensis, $B$. cereus, B. atrophaeus, Pseudomonas sp., Cedeceadavisae, Escherichia sp., Acinetobacter calcoaceticus, Lysinobacillus sp., Pantoea sp., and Citrobacter freundii. Further investigation is needed to screen these isolated endophytic bacteria for different activities known to promote plant growth and protection from phytopathogen.

\section{Introduction}

Most plants in nature associate with varied species of endophytic bacteria. About 300,000 plant species exist on the earth, and evidence suggests that most of them host one or more endophytes. However, only a few of these plants have been researched in detail with respect to their endophytic biology. Hence, expanding the search to identify new, as well as interesting, endophytic bacteria is important (Strobel et al., 2005). The term endophyte was first coinedby De Barry (endon: within; phyton: plant) (Bary, 1866). Endophytic bacteria can be referred to as bacteria that live all or part of their life cycle colonizing inter, or intra-cellular, healthy tissues of the host plant, without causing symptomatic effects to the plant (Wilson, 1995). Endophytic bacteria found in plant 
hosts comprise several genera and species. Evidence suggests that mostly every plant is populated with a diversity of endophytes. The interactions between endophyte communities inside plants are not well understood; however, it has been anticipated that beneficial effects are the combined result of their activities. Distribution of endophytic bacteria within plants depends on their ability to colonize and obtain plant resources. Endophytes can enter the plant tissues through the root zone or aerial portions of plants (Kobayashi and Palumbo, 2000), while they also have the ability to colonize different compartments of the plant apoplast, including the intercellular spaces of the cell walls, and xylem vessels, as well as reproductive organs of plants, including flowers, fruits and seeds. These bacteria do not normally cause any morphological changes, or symptoms of disease in the plant. However, many endophytic bacteria can positively influence plant growth. Most studies show that the main source of these endophytic colonizers is the rhizosphere (Hallmann et al., 2006), but can also include the phyllosphere, anthosphere, and seeds (Compant et al., 2005). Endophytes contact and colonize the host plant through cracks formed at the emergence of lateral roots or at the zone of elongation and differentiation of the root, then can quickly spread to the intercellular spaces in the root (Chi et al., 2005). For instance Klebsiella strain Kp342 forms aggregates at lateral-root junctions of wheat and alfalfa (Dong et al., 2003).Cellulolytic and pectinolytic enzymes produced by these endophytes contribute to efficiency in contacting and colonizing the host (Hallmann et al., 1997). For example, in Klebsiella strains, pectate lyase is involved in plant colonization (Kovtunovych et al., 1999).

Different plant hosts have different susceptibilities to being colonized by the same bacterial endophytes. For example, two Klebsiella strains differ in their occupation in different plant hosts (Medicago sativa, Arabidopsis thaliana, Triticumaestivum and Oryza sativa). One of the bacteria (Kp342) was a better colonizer in all hosts, and it needed only a single cell to colonize the plants (Dong et al., 2003). Endophytic bacteria can be located inside different parts of a plant, such as roots, stems, leaves, seeds, fruits, and also inside legume nodules (Hallmann et al., 1997). As a rule, more endophytes are found in the roots of plants than other plant parts (Rosenblueth and Martínez-Romero, 2006). Endophytic bacteria have the ability to penetrate the plant cell wall and become systemically spread throughout the host plant, sometimes actively colonizing the apoplast, and conducting vessels (Hallmann et al., 1997), and occasionally the intracellular spaces. Most researchers have found that intercellular spaces and xylem vessels are the most common locations for endophytic bacteria (Reinhold-Hurek and Hurek, 1998).

Some endophytic bacteria have positive effects on the host plant. These may include the promotion of plant growth by producing various compounds, providing the plant with nutrients, and antagonizing plant pathogens through biological control. Plants severely restrict the endophytes growth, while the endophytic bacteria employ a number of mechanisms to slowly conform to their surroundings. In order to maintain a stable symbiosis, endophytes secrete a number of compounds, which enhance plants' growth and assist the endophytes in adapting better to the surroundings (Uma Maheswari et al., 2013).

Different mechanisms are employed by endophytic bacteria to promote plant growth. These include both direct and indirect mechanisms. Direct mechanisms include facilitating nutrient acquisition through the fixation of nitrogen, solubilization of 
phosphate, production of siderophores, production of phytohormones (such as auxins, cytokinins, and gibberellins), or production of the enzyme1- aminocyclopropane-1carboxylate (ACC) deaminase (Tsavkelova et al., 2006). Indirect mechanisms entail prevention of infections by pathogens, via production of antibacterial or antifungal agents, or outcompeting pathogens for nutrients (Nair and Padmavathy, 2014).

There has been a great deal of interest in recent years among investigators concerning endophytic bacteria, which has been facilitated by newly available and applied molecular techniques for their isolation and identification (Hallmann et al., 1997). Generally, the endophytic bacterial community aids in enhancing crop production and health.

The development of selected endophytic bacterial strains that can promote plant growth could be one of many new approaches that are needed to aid the growth and health of agricultural plants. Isolation and development of beneficial endophytes could lead researchers using them as commercial products to help eliminate or minimize commercial fertilizers, and allow practices to conserve organic and inorganic soil nutrients. Moreover, the ability of some endophytes to protect against plant pathogens could help minimize the use of commercial pesticides (Glick, 2012).

The objectives of this study were, to isolate endophytic bacteria from the roots of four different plants, viz. Typha (Cattail), Bromus tectorum (Downy brome or cheatgrass), Festuca. (Fescue), and Nasturtium officinale (Watercress), growing along the stream banks in Hot Springs, South Dakota; to study selected phenotypic characteristics of the recovered bacterial strains in vitro, and to identify these endophytic bacterial isolates through partial 16S-rRNA gene sequencing.

\section{Materials and Methods}

\section{Collection of plant samples}

Plant samples were collected from the banks of streams in Hot Springs, SD. As much as possible, whole plants were obtained including both root systems and aerial portions. Then, the plant samples were transported to the laboratory for processing. In the lab, the plants were kept in water at room temperature until processing.

\section{Identification of plants}

Identification of collected plants species was performed by Dr. Gary Larson (Biology/Microbiology Department, South Dakota State University, Brookings, SD). Four different plant species were identified Typha(Cattail), Bromus tectorum (Downy brome or cheatgrass), Festuca (Fescue), and Nasturtium officinale (Watercress).

\section{Isolation of putative endophytic bacteria from plants}

Thirty-three bacterial strains were recovered from the collected plant samples. Twenty-five of these strains were isolated from roots of monocotyledons plants, Typha, Bromus tectorum, and Festuca. The remaining eight strains were isolated from roots of dicotyledons plants, Nasturtium officinale. For the isolation of endophytes, plant samples were showing healthy appearing (no disease symptoms), and subsequently were washed with sterile tap water to remove soil. These were further treated with $70 \%$ ethanol for 10 seconds, then $1 \%$ chloramine-T for 10 minutes with vigorous shaking, and then washed with sterile distilled water several times to remove chloramine- $T$.

After the treatment with chloramine-T, the roots were cut into 0.5 to $1 \mathrm{~cm}$ sections with 
sterile surgical blade under aseptic conditions. The samples of roots were placed on a plate of nutrient-agar medium (Difco), or J-agar medium $(5 \mathrm{~g}$ tryptone, $15 \mathrm{~g}$ yeast extract, $3 \mathrm{~g}$ HP, 20 g-agar, 2 g-glucose, $1000 \mathrm{ml}$ distilled water, $\mathrm{pH} 7.3$ to 7.5 ), which is recommended for culturing Bacillus (Bacon and Dorothy, 2004). All plates were incubated at room temperature (25) for five days, and observed periodically for bacterial growth. Isolated colonies were re-streaked until judged to be pure cultures by uniform colony morphology.

\section{Preliminary characterization of putative endophytic bacterial strains}

All the thirty-three bacterial isolates mentioned above were evaluated for Gram stain, potassium hydroxide $(\mathrm{KOH})$ "string test" (Sutton, 2006), and colony morphology.

Identification of the putative endophytic bacterial isolates by $16 \mathrm{~S}$ rRNA partial sequencing

The selected bacterial isolates were cultured on medium for extraction of genomic DNA for $16 \mathrm{~S}$ rRNA gene analysis to identify strains.

\section{Extraction of genomic DNA for 16S rRNA} sequence analysis

Twenty-seven bacterial isolates were amenable to extraction of their genomic DNA in our SDSU laboratory. Genomic DNA was obtained from bacterial colonies by growing them on NA medium for $24 \mathrm{~h}$ at $28^{\circ} \mathrm{C}$ using a commercial bacterial genomic DNA extraction (Zymo research miniprep kit, Zymo Research Corporation, Irvine, CA) following manufacturer instructions.

Colonies were suspended in $1 \mathrm{ml}$ sterile distilled water in Eppendorf tubes and centrifuged at $10.000 \mathrm{xg}$ for $5 \mathrm{~min}$ and the supernatant discarded. Briefly, pellets were suspended in $750 \mu \mathrm{L}$ lysis solution and vortexed for $5 \mathrm{~min}$, followed by centrifugation at $10000 \mathrm{xg}$ for $1 \mathrm{~min} .400 \mu \mathrm{L}$ of the upper aqueous phase was aliquoted into a new Eppendorf tube and centrifuged at 7000 xgfor $1 \mathrm{~min} .1200 \mu \mathrm{L}$ of buffer was added to the filtrate and $800 \mu \mathrm{L}$ of the mixture was transferred to the new collection tube and centrifuged at $10.000 \mathrm{xg}$ for $1 \mathrm{~min}$. The filtered DNA was pre-washed by adding 200 $\mu \mathrm{L}$ DNA pre-wash buffer and centrifuged at $10.000 \mathrm{xg}$ for $1 \mathrm{~min}$. $500 \mu \mathrm{L}$ of DNA wash buffer was added to the new collection tube and centrifuged at $10.000 \mathrm{xg}$ for $1 \mathrm{~min}$. Finally, $100 \mu \mathrm{L}$ of DNA elution buffer was added to elute the DNA in a clean $1.5 \mathrm{ml}$ micro-centrifuge tube. The concentration of DNA was visualized by agarose gel electrophoresis $(0.8 \%$ agarose gel was electrophoresis run at 80 Volt for $40 \mathrm{~min}$ ).

\section{Polymerase Chain Reaction (PCR) amplification}

The 16S rRNA gene of each strain was amplified by PCR in a $30 \mu \mathrm{L}$ reaction containing $1 \mu \mathrm{L}$ of template genomic DNA, $0.125 \mu \mathrm{L}$ Taq DNA polymerase, $3 \mu \mathrm{L}$ Taq buffer, $0.6 \mu \mathrm{L}$ dNTP, $2.4 \mu \mathrm{L} \mathrm{Mg}$, and $0.6 \mu \mathrm{L}$ gene-specific primers $27 \mathrm{f}$ (5'GAGTTTGATCCTGGCTCA-3'), and reverse primer $518 \mathrm{r}\left(5^{\prime}\right.$-GTATTA CCG CGG CTG CTGG-3'), with the addition of sterile deionized $\mathrm{O}$ to obtain a final volume of 30 $\mu \mathrm{L}$. PCR amplification was performed using a thermocycler (Eppendrof ®Mastercycler nexus $\left.{ }^{\circledR}\right)$ with the following PCR conditions for 50 cycles, initial denaturation of $94^{\circ} \mathrm{C}$ for four min, followed $94^{\circ} \mathrm{C}$ for 45 seconds. Then $50^{\circ} \mathrm{C}$ for 55 seconds, and $72^{\circ} \mathrm{C}$ for one min with a final extension of $72^{\circ} \mathrm{C}$ for $10 \mathrm{~min}$ (Ngoma et al., 2013).

The PCR product was visualized by agarose gel electrophoresis $(1 \%$ agarose gel was 
electrophoresis run at 80 volts for $40 \mathrm{~min}$ ). The PCR products with the primers were sent in 96 well plate, for sequencing (single pass PCR sequencing) by Beckman Coulter Genomics Company, (36 Cherry Hill Drive, Danvers, MA; 01923 USA). Then, the sequence data were checked by BLAST analysis in the NCBI database for microbial identification. The phylogenetic analysis of the 16SrDNA sequences of the strains was conducted with MEGA 6 (Molecular Evolutionary Genetics Analysis, version 6) software, using the neighbor-joining method.

\section{Results and Discussion}

\section{Isolation of putative endophytic bacteria}

Nine strains of the bacteria were isolated from Typha, five strains from Bromus tectorum, ten strains from Festuca, and eight strains from Nasturtium officinal (Table 1).

From the surface sterilization procedure for the isolation of putative endophytic bacteria, an adequate number of colonies were obtained in the culture using nutrient agar and J-agar media plates. Based on the distinct colony characteristics, the bacterial isolates obtained from 10 plates of nutrient agar (NA) and 2 plates of J-Agar $(\mathrm{J})$ were grouped into different groups named as M1RNA, M2RNA, M3RNA, M4RNA, M2RJA, M3RJA, and D1RNA. Each distinct colony type was characterized as a putative bacterial endophyte.

\section{Characterization of putative endophytic bacterial strains}

For morphological characterization, the putative endophytic bacterial isolates were grown on NA to look for differences between colonies, in shape, color, elevation, margin, and texture (Willgohs and Bleakley, 1999). In addition, Gram stains were performed to evaluate Gram reaction, cell shape, and arrangement. Twenty-two isolates were Gram positive and negative for the $\mathrm{KOH}$ string test.

The remaining eleven isolates were Gram negative and positive for the $\mathrm{KOH}$ string test. This diversity of morphological characteristics of putative endophytic bacterial isolates indicated that they were different bacterial species (Table 2).

\section{Identification of putative endophytic bacterial isolates by $16 \mathrm{~S}$ rRNA partial sequencing}

The 16S rRNA gene sequencing of the twenty-seven bacterial isolates were amplified and obtained from Beckman Coulter Genomics Company. The data BLAST analysis of $16 \mathrm{~S}$ rRNA gene sequences for selected bacterial isolates showed alignments of these sequences with reported $16 \mathrm{~S}$ rRNA gene sequences in the NCBI database. The highest similarities found with different bacterial genera for the bacterial isolates are summarized (Table 3 ).

The sequence analysis of $16 \mathrm{~S}$ rDNA sequences of isolated bacteria showed the maximum identity $(97 \%-100 \%)$ to different bacterial species belonging to the genera of Bacillus, Pseudomonas, Escherichia, Lysinibacillus, Acinetobacter, Pantoea, and Citrobacter. The bacterial isolates, (M2RNA 1-1, M2RNA 1-2, M3RNA4-6, M4RNA 3-4, M1RNA 10-2, M1RNA 12-1, M1RNA 12-2, M1RNA 12-3, D1RNA 7-2, D1RNA 7-3, and D1RNA8-1), Gram positive, rod shaped morphology, negative for potassium hydroxide, belonged to Bacillus thuringensis with $97 \%$ to $100 \%$ similarity. In addition, isolates (M2RNA 2-1,M2RJA 6-1,M4RNA 32,M1RNA 11-1,D1RNA 7-1, andD1RNA 135), Gram negative short rod shaped morphology, positive for potassium hydroxide, with $99 \%$ similarity, belonged to Pseudomonas sp. Isolates (M3RNA 4-3, M3RNA 4-8, and D1RNA 13-3),Gram 
positive, rod shaped morphology, negative to potassium hydroxid, belonged to Lysinibacillus sp. Isolates (M3RNA 4-2, and M1RNA 10-1) were closely related with $99 \%$ to Bacillus cereus. In addition, Gram negative, short rod shaped morphology, positive to potassium hydroxide, (M3RNA 45, and D1RNA 8-2) isolates, denominated with $98 \%$ to $99 \%$ to be members of
Citrobacter fruendii. Similarly, isolate (M2RJA 6-2) had a sequence similarity of $99 \%$, to the type strain of Pantoea sp. The two isolates (M3RJA 5-1 and M3RJA 5-2) were classified as Cedeceadavisae/ Escherichia hermannii and Escherichia sp. (M1RNA 11-4) isolate belonged to Bacillus atrophaeus.

Fig.1 Phylogenetic analysis of 16S rRNA sequences of the putative endopytic bacterial isolates

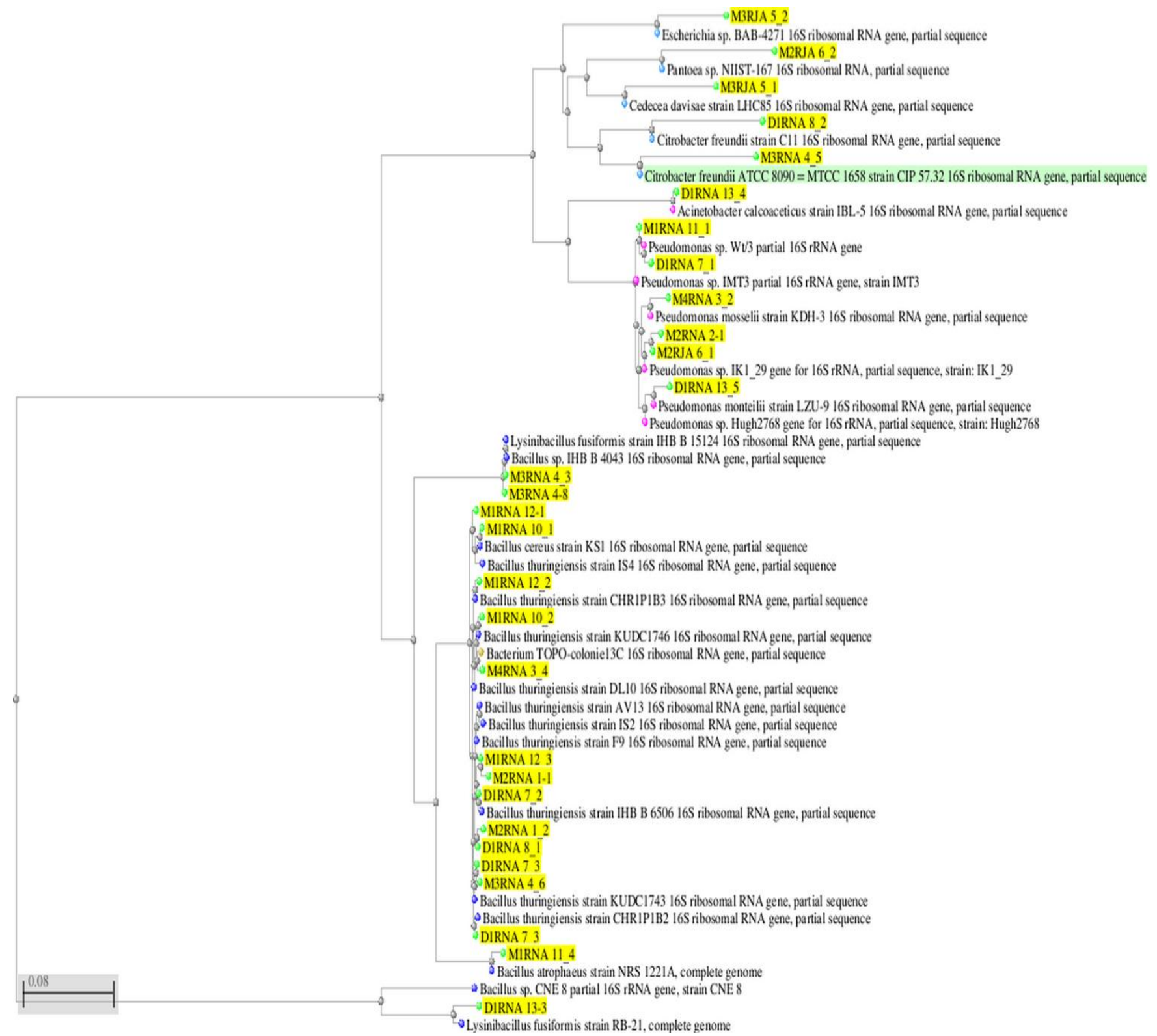


Table.1 Isolation of putative endophytic bacteria from monocotyledon and dicotyledon plants

\begin{tabular}{|c|c|c|c|}
\hline Type of plant & $\begin{array}{c}\text { Number of } \\
\text { bacteria isolated }\end{array}$ & $\begin{array}{c}\text { Scientific name of the } \\
\text { plant }\end{array}$ & $\begin{array}{c}\text { Common name for the } \\
\text { plant }\end{array}$ \\
\hline Monocot 1 & 9 & Typha & Cattail. \\
Monocot 2 & 5 & Bromus tectorum & Downy brome, Cheatgrass. \\
Monocot 3 & 9 & Festuca. & Fescue \\
Monocot 4 & 2 & Festuca. & Fescue. \\
Dicot 1 & 8 & Nasturtium officinale & Watercress. \\
\hline
\end{tabular}

Table. 2 The morphological characteristics of putative endophytic bacteria on Nutrient Agar (NA)

\begin{tabular}{|c|c|c|c|c|c|c|c|}
\hline $\begin{array}{l}\text { Plate } \\
\text { Code }\end{array}$ & $\begin{array}{l}\text { Plate } \\
\text { number }\end{array}$ & $\begin{array}{l}\text { Culture } \\
\text { number }\end{array}$ & $\begin{array}{l}\text { KOH } \\
\text { test }\end{array}$ & $\begin{array}{l}\text { Gram } \\
\text { Result }\end{array}$ & $\begin{array}{l}\text { Gram } \\
\text { Morphology }\end{array}$ & $\begin{array}{l}\text { Cell } \\
\text { Morphology }\end{array}$ & Cultural Morphology \\
\hline \multirow[t]{2}{*}{ M2RNA } & 1.00 & 1.00 & Negative & Positive & $\begin{array}{l}\text { Singles and } \\
\text { clumps }\end{array}$ & Rods & $\begin{array}{l}\text { circular, Entire, flat, large, rough, dull, } \\
\text { non-pigmented, opaque }\end{array}$ \\
\hline & & 2.00 & Negative & Positive & Chains & Rods & $\begin{array}{l}\text { circular, curled, flat, large, rough, dull, } \\
\text { non-pigmented, opaque }\end{array}$ \\
\hline M2RNA & 2.00 & 1.00 & Positive & Negative & Clumps & Short rods & $\begin{array}{l}\text { circular, Entire, raised, small, smooth, } \\
\text { shiny, non-pigmented, opaque }\end{array}$ \\
\hline \multirow[t]{2}{*}{ M4RNA } & 3.00 & 2.00 & Positive & Negative & $\begin{array}{l}\text { Singles and } \\
\text { clumps }\end{array}$ & Short rods & $\begin{array}{l}\text { circular, entire, convex, small, smooth, } \\
\text { shiny, pigmented, opaque }\end{array}$ \\
\hline & & 4.00 & Negative & Positive & $\begin{array}{l}\text { Single and } \\
\text { chain }\end{array}$ & Rods & $\begin{array}{l}\text { circular, curled, raised, large, rough, } \\
\text { dull, } \\
\text { non-pigmented, opaque }\end{array}$ \\
\hline \multirow[t]{7}{*}{ M3RNA } & 4.00 & 1.00 & Negative & Positive & Chains & Rods & $\begin{array}{l}\text { circular, curled, raised, large, rough, } \\
\text { dull, non-pigmented, opaque }\end{array}$ \\
\hline & & 2.00 & Negative & Positive & $\begin{array}{l}\text { Chains and } \\
\text { clumps }\end{array}$ & Rods & $\begin{array}{l}\text { circular, entire, flat, moderate, rough, } \\
\text { dull, non-pigmented, opaque }\end{array}$ \\
\hline & & 3.00 & Negative & Positive & Clumps & Rods & $\begin{array}{l}\text { circular, entire, raised, small, smooth, } \\
\text { shiny, non-pigmented, opaque }\end{array}$ \\
\hline & & 5.00 & Positive & Negative & Clustered & Short rods & $\begin{array}{l}\text { circular, entire, flat, small, smooth, } \\
\text { shiny, non-pigmented, opaque }\end{array}$ \\
\hline & & 6.00 & Negative & Positive & Chains & Rods & $\begin{array}{l}\text { circular, curled, flat, moderate, rough, } \\
\text { dull, non-pigmented, opaque }\end{array}$ \\
\hline & & 7.00 & Negative & Positive & $\begin{array}{l}\text { Single and } \\
\text { clumps }\end{array}$ & Rods & $\begin{array}{l}\text { circular, curled, raised, large, rough, } \\
\text { dull, non-pigmented, opaque }\end{array}$ \\
\hline & & 8.00 & Negative & Positive & $\begin{array}{l}\text { Chains and } \\
\text { clumps }\end{array}$ & Rods & $\begin{array}{l}\text { circular, entire, convex, punctiform, } \\
\text { smooth, shiny, non-pigmented, opaque }\end{array}$ \\
\hline \multirow[t]{2}{*}{ M3RJA } & 5.00 & 1.00 & Positive & Negative & Clustered & Coccobacilli & $\begin{array}{l}\text { circular, entire, raised, small, smooth, } \\
\text { shiny, non-pigmented, opaque }\end{array}$ \\
\hline & & 2.00 & Positive & Negative & Clustered & Coccobacilli & $\begin{array}{l}\text { circular, entire, flat, small, smooth, } \\
\text { shiny, non-pigmented, opaque }\end{array}$ \\
\hline \multirow[t]{2}{*}{ M2RJA } & 6.00 & 1.00 & Positive & Negative & Clumps & Short rods & $\begin{array}{l}\text { circular, entire, raised, small, smooth, } \\
\text { shiny, non-pigmented, opaque }\end{array}$ \\
\hline & & 2.00 & Negative & Positive & $\begin{array}{l}\text { Clumps and } \\
\text { single }\end{array}$ & Coccobacilli & $\begin{array}{l}\text { circular, entire, raised, small, smooth, } \\
\text { shiny, } \\
\text { non-pigmented, opaque }\end{array}$ \\
\hline \multirow[t]{2}{*}{ D1RNA } & 7.00 & 1.00 & Positive & Negative & $\begin{array}{l}\text { Single and } \\
\text { clumps }\end{array}$ & Short rods & $\begin{array}{l}\text { circular, rhizoid, flat, small, } \\
\text { smooth, shiny, non-pigmented, opaque }\end{array}$ \\
\hline & & 2.00 & Negative & Positive & Chains & Rods & $\begin{array}{l}\text { circular, entire, raised, large, rough, } \\
\text { dull, non-pigmented, opaque. }\end{array}$ \\
\hline
\end{tabular}


Int.J.Curr.Microbiol.App.Sci (2017) 6(6): 756-767

\begin{tabular}{|c|c|c|c|c|c|c|c|}
\hline $\begin{array}{l}\text { Plate } \\
\text { Code }\end{array}$ & $\begin{array}{l}\text { Plate } \\
\text { number }\end{array}$ & $\begin{array}{l}\text { Culture } \\
\text { number }\end{array}$ & $\begin{array}{l}\text { KOH } \\
\text { test }\end{array}$ & $\begin{array}{l}\text { Gram } \\
\text { Result }\end{array}$ & $\begin{array}{l}\text { Gram } \\
\text { Morphology }\end{array}$ & $\begin{array}{l}\text { Cell } \\
\text { Morphology }\end{array}$ & $\begin{array}{l}\text { Cultural } \\
\text { Morphology }\end{array}$ \\
\hline & & 3.00 & Negative & Positive & $\begin{array}{l}\text { Chains and } \\
\text { clumps }\end{array}$ & Rods & $\begin{array}{l}\text { circular, entire, flat, moderate, rough, } \\
\text { dull, non-pigmented, opaque }\end{array}$ \\
\hline \multirow[t]{2}{*}{ D1RNA } & 8.00 & 1.00 & Positive & Negative & $\begin{array}{l}\text { Chains and } \\
\text { clumps }\end{array}$ & Rods & $\begin{array}{l}\text { circular, entire, raised, small, smooth, } \\
\text { shiny, non-pigmented, opaque }\end{array}$ \\
\hline & & 2.00 & Positive & Negative & $\begin{array}{l}\text { Singles and } \\
\text { chump }\end{array}$ & Short rods & $\begin{array}{l}\text { circular, entire, raised, small, rough, } \\
\text { dull, non-pigmented, opaque }\end{array}$ \\
\hline \multirow[t]{2}{*}{ M1RNA } & 10.00 & 1.00 & Negative & Positive & $\begin{array}{l}\text { Chains and } \\
\text { clumps }\end{array}$ & Rods & $\begin{array}{l}\text { circular, entire, raised, large, rough, } \\
\text { dull, non-pigmented, opaque }\end{array}$ \\
\hline & & 2.00 & Negative & Positive & $\begin{array}{l}\text { Chains and } \\
\text { clumps }\end{array}$ & Rods & $\begin{array}{l}\text { circular, entire, raised, moderate, } \\
\text { rough, dull, non-pigmented, opaque }\end{array}$ \\
\hline \multirow[t]{4}{*}{ M1RNA } & 11.00 & 1.00 & Positive & Negative & Clumps & Short rods & $\begin{array}{l}\text { circular, Entire, raised, small, smooth, } \\
\text { shiny, non-pigmented, opaque }\end{array}$ \\
\hline & & 2.00 & Positive & Negative & $\begin{array}{l}\text { Singles and } \\
\text { clumps }\end{array}$ & Short rods & $\begin{array}{l}\text { circular, entire, raised, small, smooth, } \\
\text { shiny, non-pigmented, opaque }\end{array}$ \\
\hline & & 3.00 & Negative & Positive & $\begin{array}{l}\text { Chains and } \\
\text { single }\end{array}$ & Rods & $\begin{array}{l}\text { circular, entire, raised, moderate, } \\
\text { rough, dull, non-pigmented, opaque }\end{array}$ \\
\hline & & 4.00 & Negative & Positive & $\begin{array}{l}\text { Singles and } \\
\text { clumps }\end{array}$ & Rods & $\begin{array}{l}\text { Irregular, entire, Raised, moderate, } \\
\text { smooth, shiny, non-pigmented, } \\
\text { translucent }\end{array}$ \\
\hline \multirow[t]{3}{*}{ M1RNA } & 12.00 & 2.00 & Negative & Positive & $\begin{array}{l}\text { Singles and } \\
\text { clumps }\end{array}$ & Rods & $\begin{array}{l}\text { circular, entire, raised, large, rough, } \\
\text { dull, non-pigmented, opaque }\end{array}$ \\
\hline & & 3.00 & Negative & Positive & Chains & Rods & $\begin{array}{l}\text { circular, entire, raised, moderate, } \\
\text { rough, dull, non-pigmented, opaque }\end{array}$ \\
\hline & & 1.00 & Negative & Positive & $\begin{array}{l}\text { Chains and } \\
\text { clumps }\end{array}$ & Rods & $\begin{array}{l}\text { circular, entire, raised, moderate, } \\
\text { rough, dull, non-pigmented, opaque }\end{array}$ \\
\hline \multirow[t]{3}{*}{ D1RNA } & 13.00 & 3.00 & Negative & Positive & $\begin{array}{l}\text { Chains and } \\
\text { clumps }\end{array}$ & Rods & $\begin{array}{l}\text { circular, entire, raised, small, smooth, } \\
\text { shiny, non-pigmented, opaque }\end{array}$ \\
\hline & & 4.00 & Negative & Positive & Clustered & Coccobacilli & $\begin{array}{l}\text { circular, Entire, flat, small, smooth, } \\
\text { shiny, non-pigmented, translucent }\end{array}$ \\
\hline & & 5.00 & Positive & Positive & Clumps & Short rods & $\begin{array}{l}\text { circular, filamentous, flat, small, } \\
\text { smooth, shiny, non-pigmented, opaque }\end{array}$ \\
\hline
\end{tabular}

$* \mathrm{M}=$ Monocot plant. $* \mathrm{D}=$ Dicot plant. $* \mathrm{R}=$ Isolated from Root. $* \mathrm{NA}=$ Nutrient Agar. $* \mathrm{JA}=\mathrm{J}-$ Agar. 
Table.3 Identity of putative endophytic bacterial isolates by alignment of $16 \mathrm{~S}$ rRNA gene sequences

\begin{tabular}{|c|c|c|c|c|c|c|}
\hline $\begin{array}{l}\text { Isolate } \\
\text { code }\end{array}$ & $\begin{array}{c}\text { Sequence } \\
\text { length } \\
\text { (bp) }\end{array}$ & $\begin{array}{c}\text { Closest related in } \\
\text { database }\end{array}$ & $\begin{array}{c}\text { Accession } \\
\text { number in } \\
\text { NCBI }\end{array}$ & $\begin{array}{c}\text { Similarity } \\
(\%)\end{array}$ & $\begin{array}{c}\text { E- } \\
\text { value }\end{array}$ & Plant name \\
\hline M2RNA 1-1 & 484 & Bacillus thuringiensis & HQ432809.1 & $100 \%$ & 0 & Bromus tectorum \\
\hline M2RNA 2-1 & 517 & Pseudomonas sp. & $\mathrm{AB} 247229.1$ & $99 \%$ & 0 & Bromus tectorum \\
\hline M2RNA 1-2 & 1517 & Bacillus thuringiensis & KF475852.1 & $99 \%$ & 0 & Bromus tectorum \\
\hline M2RJA 6-1 & 517 & Pseudomonas sp. & AB247229.1 & $99 \%$ & 0 & Bromus tectorum \\
\hline M2RJA 6-2 & 2097 & Pantoea sp. & FJ445213.1 & $99 \%$ & 0 & Bromus tectorum \\
\hline M3RNA 4-1 & 537 & Bacillus thuringiensis & $\mathrm{C} 1504156520$ & $97 \%$ & 0 & Festuca. \\
\hline M3RNA 4-2 & 537 & Bacillus cereus & C1504156521 & $99 \%$ & 0 & Festuca. \\
\hline M3RNA 4-3 & 1506 & Lysinibacillus fusiformis & KM817206.1 & $99 \%$ & 0 & Festuca. \\
\hline M3RNA 4-5 & 784 & Citrobacterfreundii & JQ267509.1 & $99 \%$ & 0 & Festuca. \\
\hline M3RNA 4-6 & 1517 & Bacillus thuringiensis & KP284269.2 & $99 \%$ & 0 & Festuca. \\
\hline M3RNA 4-7 & 537 & Bacillus thuringiensis & C1504156522 & $97 \%$ & 0 & Festuca. \\
\hline M3RNA 4-8 & 1506 & Lysinibacillus fusiformis & KM817206.1 & $99 \%$ & 0 & Festuca. \\
\hline M3RJA 5-1 & 1385 & $\begin{array}{c}\text { Cedeceadavisael } \\
\text { Escherichia hermannii }\end{array}$ & $\begin{array}{l}\text { KC951923.1 } \\
\text { HF585334.1 }\end{array}$ & $99 \%$ & 0 & Festuca. \\
\hline M3RJA 5-2 & 1505 & Escherichia sp. & KJ855238.1 & $99 \%$ & 0 & Festuca. \\
\hline M4RNA 3-2 & 1531 & Pseudomonas mosselii & KF784932.1 & $99 \%$ & 0 & Festuca. \\
\hline M4RNA 3-4 & 1518 & Bacillus thuringiensis & KJ767310.1 & $99 \%$ & 0 & Festuca. \\
\hline M1RNA10-1 & 1066 & Bacillus cereus & JQ912681.1 & $99 \%$ & 0 & Typha \\
\hline M1RNA10-2 & 1517 & Bacillus thuringiensis & KF475852.1 & $99 \%$ & 0 & Typha \\
\hline M1RNA11-1 & 1484 & Pseudomonas $s p$ & FR823441.1 & $99 \%$ & 0 & Typha \\
\hline M1RNA11-2 & 522 & $\begin{array}{c}\text { Pseudomonas } \\
\text { entomophila } \\
\text { P. monteillii/P.putida }\end{array}$ & C1504156523 & $100 \%$ & 0 & Typha \\
\hline M1RNA11-3 & 537 & Bacillus thuringiensis & C1504156524 & $97 \%$ & 0 & Typha \\
\hline M1RNA11-4 & 1559 & Bacillus atrophaeus & NR_075016.1 & $99 \%$ & 0 & Typha \\
\hline M1RNA12-1 & 512 & Bacillus thuringiensis & FJ755917.1 & $99 \%$ & 0 & Typha \\
\hline M1RNA12-2 & 1517 & Bacillus thuringiensis & KP284269.2 & $99 \%$ & 0 & Typha \\
\hline M1RNA12-3 & 515 & Bacillus thuringiensis & FJ755919.1 & $99 \%$ & 0 & Typha \\
\hline D1RNA7-1 & 1502 & Pseudomonas sp. & AJ785569.1 & $99 \%$ & 0 & $\begin{array}{l}\text { Nasturtium } \\
\text { officinale }\end{array}$ \\
\hline D1RNA 7-2 & 1517 & Bacillus thuringiensis & KF475852.1 & $99 \%$ & 0 & $\begin{array}{l}\text { Nasturtium } \\
\text { officinale }\end{array}$ \\
\hline D1RNA 7-3 & 1517 & Bacillus thuringiensis & KP284269.2 & $99 \%$ & 0 & $\begin{array}{l}\text { Nasturtium } \\
\text { officinale }\end{array}$ \\
\hline D1RNA 7-3 & 1517 & Bacillus thuringiensis & KP284269.2 & $99 \%$ & 0 & $\begin{array}{l}\text { Nasturtium } \\
\text { officinale }\end{array}$ \\
\hline D1RNA 8-1 & 484 & Bacillus thuringiensis & HQ432809.1 & $100 \%$ & 0 & $\begin{array}{l}\text { Nasturtium } \\
\text { officinale }\end{array}$ \\
\hline D1RNA 8-2 & 1504 & Citrobacterfreundii & KF145194.1 & $98 \%$ & 0 & $\begin{array}{l}\text { Nasturtium } \\
\text { officinale }\end{array}$ \\
\hline D1RNA13-3 & 674 & Lysinibacillus sp. & КС867319.1 & $99 \%$ & 0 & $\begin{array}{l}\text { Nasturtium } \\
\text { officinale }\end{array}$ \\
\hline D1RNA13-4 & 1485 & $\begin{array}{c}\text { Acinetobacter } \\
\text { calcoaceticus }\end{array}$ & КC900897.1 & $99 \%$ & 0 & $\begin{array}{l}\text { Nasturtium } \\
\text { officinale }\end{array}$ \\
\hline D1RNA13-5 & 1484 & Pseudomonas sp. & FR823441.1 & $99 \%$ & 0 & $\begin{array}{l}\text { Nasturtium } \\
\text { officinale }\end{array}$ \\
\hline
\end{tabular}


The identification of bacteria was further confirmed at phylogenetic level. The phylogenetic analysis of 16S rRNA sequence of the isolates along with the sequences retrieved from the NCBI database was carried out with MEGA 6 software using the neighbor-joining method. These results showed distinct clustering of the isolates (Figure 1).

The putative endophytic bacterial isolates were found associated with tissues of different plants, Typha (Cattail), Bromus tectorum (Downy brome or cheatgrass), Festuca (Fescue), and Nasturtium officinale (Watercress), growing along stream banks in Hot Springs, SD. These plants are relatively unstudied and being considered as potential source for natural products to be used in researches or agriculture fields.

In this study, a total of 33 bacterial strains were isolated from roots of different plants. The population of endophytes was found to be more in the roots than stems and leaves (Uma Maheswari et al., 2013). The surface sterilization of roots tissue after rinsing with sterilized distilled water, and by sequential immersion in $70 \%$ ethanol and $1 \%$ chloramine-T ensured the removal of surface microbial flora. These chemical disinfectants have been employed for surface sterilization of excised roots tissue to remove epiphytes microbes; however, immersion of the tissues in ethanol and chloramine- $T$ has shown significant success in different studies (Bacon and Dorothy, 2004). The processed tissues after dividing in to small pieces $(0.5 \mathrm{~cm}$ to 1 $\mathrm{cm}$ sections), with sterile surgical blade under aseptic conditions were shifted to the isolation media. The putative endophytic bacterial colonies were purified by repeated sub culturing on NA or J agar, similar results were reported by Zinniel et al., (2002). Subjection of the selected endophytic bacterial isolates to combinatory of morphological characterization, and 16S rRNA gene sequencing provided a specific identification of the bacterial isolates.

In morphological characterization, the putative endophytic bacterial isolates showed the diverse colony shapes, colors, margins and texture including round to irregular colonies, opaque to translucent with entire, curled, filamentous margins, for different endophytic bacterial isolates.

In addition, 22 among 33 putative endophytic bacteria isolates exhibited positive results for Gram staining while negative results for potassium hydroxide. In addition, 11 of the putative endophytic bacteria isolates showed negative results for Gram staining while positive results for potassium hydroxide. These results indicated that potassium hydroxide was used to ensure the Gram staining results.

Furthermore, the putative endophytic bacterial isolates were determined by $16 \mathrm{~S}$ rRNA gene sequencing. The BLAST analysis of $16 \mathrm{~S}$ rRNA gene sequence data of the putative endophytic bacterial isolates showed alignments of these sequences with the reported 16S rRNA gene sequences in NCBI. The highest similarities found with different bacterial genera and NCBI accession number for the 33 bacterial strains were summarized in table 3 .

The results indicated that the putative endophytic bacterial were isolated from Hot Springs, were found to be belonging to genera of Bacilli, Pseudomonas, Citrobacter, Acinetobacter, Pantoea, and Enterobacter after identified by $16 \mathrm{~S}$ rRNA analysis.

Using different innovative tools of biotechnology will assist in fortifying the understanding of the interactions of plants and endophyte - such as their growth in plants, 
and their secretion of new bioactive compounds, endophytes may be enhanced for biological control activity, and for decreasing the debris and other wastes that are otherwise harmful to the ecosystem. Putting all of this into consideration, endophytic bacteria have beneficial effects on the environment, industries, and agriculture. The utilization of their molecular activities that enhance our ability to better understanding and management of the endophytes could lead to new products with improved effectiveness.

\section{References}

Bacon, C.W.H. and Dorothy M. 2004. Techniques for Manipulating the Bacterial Endophyte Bacillus mojavensis. Methods in Biotechnology: Enviromental Microbiology: Methods and Protocols. A. L. R. S. John F. T. Spencer New Jersey, Humana Press Inc: 365.

Bary, A. 1866. Morphologie und physiologie der pilze, flechten und myxomyceten, W. Engelmann.

Chi, F., S.H. Shen, H.P. Cheng, Y.X. Jing, Y.G. Yanni and Dazzo, F.B. 2005. Ascending migration of endophytic rhizobia, from roots to leaves, inside rice plants and assessment of benefits to rice growth physiology. Appl. Environ. Microbiol., 71(11): 7271-7278.

Compant, S., B. Duffy, J. Nowak, C. Clément and Barka, E.A. 2005. Use of plant growth-promoting bacteria for biocontrol of plant diseases: principles, mechanisms of action, and future prospects. Appl. Environ. Microbiol., 71(9): 4951-4959.

Dong, Y., A.L. Iniguez and Triplett, E.W. 2003. Quantitative assessments of the host range and strain specificity of endophytic colonization by Klebsiella pneumoniae 342. Plant and Soil, 257(1): 49-59.
Glick, B.R., D.M. Penrose and J. Li, J. 1998. A model for the lowering of plant ethylene concentrations by plant growth-promoting bacteria. $J$. Theoretical Biol., 190(1): 63-68.

Hallmann, J., A. Quadt-Hallmann, W. Mahaffee and Kloepper, J. 1997. Bacterial endophytes in agricultural crops. Canadian J. Microbiol., 43(10): 895-914.

Hallmann, J., G. Berg and Schulz, B. 2006. Isolation procedures for endophytic microorganisms. Microbial root endophytes, Springer, 299-319.

Kobayashi, D. and Palumbo, J. 2000. Bacterial endophytes and their effects on plants and uses in agriculture. Microbial Endophytes, 199-233.

Kovtunovych, G., O. Lar, S. Kamalova, V. Kordyum, D. Kleiner and Kozyrovska, N. 1999. Correlation between pectate lyase activity and ability of diazotrophic Klebsiella oxytoca VN 13 to penetrate into plant tissues. Plant and Soil, 215(1): 1-6.

Nair, D.N. and Padmavathy, S. 2014. Impact of endophytic microorganisms on plants, environment and humans. The Scientific World J., Article ID 250693, $11 \mathrm{pp}$.

Ngoma, L., B. Esau and Babalola, O.O. 2013. Isolation and characterization of beneficial indigenous endophytic bacteria for plant growth promoting activity in Molelwane Farm, Mafikeng, South Africa. African J. Biotechnol., 12(26): 4105-4114.

Reinhold-Hurek, B. and Hurek, T. 1998. Life in grasses: diazotrophic endophytes. Trends in Microbiol., 6(4): 139-144.

Rosenblueth, M. and Martínez-Romero, E. 2006. Bacterial Endophytes and Their Interactions with Hosts. Mol. PlantMicrobe Interactions, 19(8): 827-837.

Strobel, G., B. Daisy and Castillo, U. 2005. The biological promise of microbial 
endophytes and their natural products. Plant Pathol. J., 4(2): 161-176.

Sutton, S. 2006. The Gram Stain, the Microbiology Network.

Tsavkelova, E., S.Y. Klimova, T. Cherdyntseva and Netrusov, A. 2006. Microbial producers of plant growth stimulators and their practical use: a review. Appl. Biochem. Microbiol., 42(2): 117-126.

UmaMaheswari, T., K. Anbukkarasi, T. Hemalatha and Chendrayan, K. 2013. Studies on phytohormone producing ability of indigenous endophytic bacteria isolated from tropical legume crops. Int. J. Curr. Microbiol. App. Sci., 2(6): 127-136.
Willgohs, J. and Bleakley, B. 1999. Laboratory Manual for General Microbiology, Pearson Custom Publishing.

Wilson, D. 1995. Endophyte: the evolution of a term, and clarification of its use and definition. Oikos, 274-276.

Zinniel, D.K., P. Lambrecht, N.B. Harris, Z. Feng, D. Kuczmarski, P. Higley, C.A. Ishimaru, A. Arunakumari, R.G. Barletta and A.K. Vidaver, A.K. 2002. Isolation and characterization of endophytic colonizing bacteria from agronomic crops and prairie plants. Appl. Environ. Microbiol., 68(5): 21982208.

\section{How to cite this article:}

Mada Faisal Ashkan and Bruce Bleakley. 2017. Isolation, characterization and identification of putative bacterial endophytes from some plants in hot springs, South Dakota. Int.J.Curr.Microbiol.App.Sci. 6(6): 756-767. doi: https://doi.org/10.20546/ijcmas.2017.606.089 